\title{
MATHEMATICS AND ETHICS
}

\author{
MATEMÁTICA E ÉTICA
}

Ole Skovsmose ${ }^{1}$

\begin{abstract}
In the philosophy of mathematics, ontological and epistemological questions have been discussed for centuries. These two set of questions span out a two-dimensional philosophy of mathematics. I find it important to establish a four dimensional philosophy of mathematics by adding two more dimensions, namely a sociological and an ethical dimension. The sociological dimension addresses the social formation of mathematics, while the ethical dimension addresses the mathematical formation of the social. In this article, I concentrate on exploring the ethical dimension by showing the broad range of social implications set in motion through bringing mathematics into action. These implications I illustrate in terms of quantifying, digitalising, serialising, categorising, and imagining. By the banality of mathematical expertise, I refer to the phenomenon that the formation of this expertise takes place in an ethical vacuum. To me this is a devastating feature of mathematical research and application practices. It is important that a philosophy of mathematics brings mathematics out of this vacuum.
\end{abstract}

Keywords: Four-dimensional philosophy of mathematics; Ethics; Mathematics in action; Quantification; Digitalization.

Resumo: Na filosofia da matemática, questões ontológicas e epistemológicas são discutidas há séculos. Esses dois conjuntos de perguntas abrangem uma filosofia bidimensional da matemática. Considero importante estabelecer uma filosofia quadrimensional da matemática, acrescentando mais duas dimensões, a saber, uma sociológica e uma ética. A dimensão sociológica aborda a formação social da matemática, enquanto a dimensão ética aborda a formação matemática do social. Neste artigo, concentro-me em explorar a dimensão ética, mostrando a ampla gama de implicações sociais acionadas ao colocar a matemática em ação. Ilustro essas implicações em termos de quantificação, digitalização, serialização, categorização e imaginação. Pela banalidade da perícia matemática, refiro-me ao fenômeno de que a formação dessa perícia ocorre em um vácuo ético. Para mim, essa é uma característica devastadora das práticas de pesquisa e aplicação matemática. É importante que uma filosofia da matemática tire a matemática desse vácuo.

Palavras-chave: Filosofia quadridimensional da matemática; Ética; Matemática em ação; Quantificação; Digitalização.

\section{Introduction}

In the philosophy of mathematics, ontological and epistemological issues have been discussed for centuries. Platonism provides a classic position. Mathematical entities have a real existence, although not in the experiential world, but in the world of ideas. Knowledge about this world cannot be obtained through our senses, only through our rationality. Logicism, formalism, and intuitionism also concentrate on questions about the nature of mathematical objects and how one can come to know about them. ${ }^{2}$

\footnotetext{
1 Aalborg University, Denmark. Universidade Estadual Paulista (UNESP), Brazil. E-mail: osk@hum.aau.dk

${ }^{2}$ See, for instance, Frege (1978), Hilbert (1922), and Brouwer (1913).
} 
Ontological and epistemological questions span out a two-dimensional philosophy of mathematics. Many elaborations of the philosophy of mathematics can be located within these two dimensions. ${ }^{3}$ In our book, Connecting Humans to Equations, Ole Ravn and I (2019) acknowledge the importance of addressing ontological and epistemological issues, but we point out that two more dimensions need to be added to a philosophy of mathematics, namely a sociological and an ethical dimension. ${ }^{4}$

The sociological dimension addresses the social formation of mathematics, exploring how mathematical notions and theories are formed through complex social processes. The existence of such a formation has been pointed out by Ludwig Wittgenstein $(1978,1989)$ by showing the significance of rule following in mathematics. In human linguistic communication, the structure and conventions, in other words the grammar, is composed of rules, which define what becomes considered correct language formulations. Such rules have a history; they develop over time. Wittgenstein indicates that the same might be true of mathematical rules. The social formation of mathematics has also been explored by Sal Restivo (1992), and in the book Social Constructivism as a Philosophy of Mathematics, Paul Ernest (1998) elaborates in great detail on the social dimension of a philosophy of mathematics. ${ }^{5}$

In this paper, I concentrate on mapping out the ethical dimension of a philosophy of mathematics. I find that the extant philosophy of mathematics, as inspired by the classics, has been operating in an ethical vacuum, and I want to bring the philosophy of mathematics out of this vacuum. Ethical issues with respect to mathematics have been addressed by Ernest $(2016,2018)$, and his concerns resonate with Ole Ravn's and my own (2019).

The notion of "mathematics" is a tricky one. It can refer to school mathematics, engineering mathematics, pure mathematics, applied mathematics, street mathematics, any kind of ethnomathematics. When in the following I elaborate on the ethical dimension of a philosophy of mathematics, I have first of all in mind what could be referred to as academic mathematics. However, the ethical dimension of a philosophy of mathematics needs a number of further elaborations in order to address any of the many versions of mathematics we practice.

\footnotetext{
${ }^{3}$ As examples, I can refer to Bernacerraf and Putnam (1964), Bostock (2009), Brown (2008), George and Velleman (2002), Jacquette (2002), Körner (1968), Linnebo (2017), Mehlberg (1960), and Shapiro (2000).

${ }^{4}$ See also Hacking (2014) for a discussion of the possible scope of a philosophy of mathematics, and Bueno and Linnebo (2009) for opening towards new issues.

${ }^{5}$ See also Restivo, Bendegem and Fisher (1993).
} 
In 1990, Ruben Hersh published a paper with the title "Mathematics and Ethics". This is the same title as I have given this paper, so let us take a look at what Hersh had in mind. Hersh tried to relate mathematics and ethics by paying attention to the professional conduct of mathematicians. According to Hersh (1990) such conduct concerns the mathematicians' relationships to "staff, students, colleagues, administrators, and ourselves" (p. 21). ${ }^{6} \mathrm{I}$ am not going to follow up on this rather profession oriented approach. I want to elaborate the connections between mathematics and ethics with a much broader socio-political perspective. I will do so taking the following steps:

First, I will present a performative interpretation of mathematics that focusses on what can be done by bringing mathematics into action. Next, I will explore such actions by addressing processes of quantifying, digitalising, serialising, categorising, and imagining. I will illustrate how such processes bring us deep into controversial ethical issues. Finally, I will address the notion of "banality of mathematical expertise", which refers to the phenomenon that mathematics, as exercised at universities and other research contexts, does not address any such issues.

\section{Mathematics in Action}

I start by drawing a distinction between a descriptive and a performative interpretation of mathematics. The descriptive interpretation has been expressed in many ways, and a powerful one was given by Ludwig Wittgenstein (1992) in the Tractatus, first published in a German-English parallel edition in 1922. Here he describes language as forming pictures of reality. However, according to Wittgenstein, it is a particular type of language that can do such a picturing, namely a formal language. Such a language was specified by Alfred Whitehead and Bertrand Russell (1910-1913) in Principia Mathematica, and anticipated by Gottlob Frege (1967) in the Begriffsschrift, the first German version of which was published in 1879.

In the $\S 6$ of the Tractatus, Wittgenstein presents a condensed formulation of what he claims to be the general form of a statement. ${ }^{7}$ Wittgenstein sees the truth value of any

\footnotetext{
6 The American Mathematical Society has published ethical guidelines for mathematical researchers highlighting the importance of avoiding plagiarism, giving credit to colleagues, publishing without unreasonable delay, and correcting errors. See Ethics in Mathematics https://en.wikipedia.org/wiki/Ethics_in_mathematics. Accessed 22 June 2020.

${ }^{7}$ In this formulation, Wittgenstein (1997) only operates with one connective, referred to as Sheffer's stroke. By means of this connective all other connectives can be defined. The $\S 6$ states: "The general form of a truth-function is: $[\bar{p}, \bar{\xi}, N(\bar{\xi})]$. This is the general form of a proposition." (p. 153)
} 
statement as defined by the truth values of the atomic statements of which it is composed. The truth values of the atomic statements are determined by their correctness in picturing reality, and the truth value of the composed statement is determined by these truth values and the well-defined logical connectives. Acknowledging the logicist outlook, Wittgenstein does not operate with any distinction between logic and mathematics, as mathematical notions and statements can be interpreted as complex logical notions and statements. As a consequence, Wittgenstein's claim becomes that mathematics is the language that provides pictures of reality. This is a radical descriptive interpretation of mathematics. ${ }^{8}$

This interpretation can be contrasted with a performative interpretation of mathematics. Inspiration for such an alternative interpretation can be found in performative interpretations of language. An important one was presented by Wittgenstein himself in the Philosophical Investigations first published in 1953 (Wittgenstein 1997). Here he coins the notion of "language game". By talking about "games", he highlights the active part of language. John Austin (1962) also distanced himself from any descriptive interpretation of language by showing that one can "do things with words", as stated in the title of one of his books. John Searle (1969) turns the performative interpretation of language explicit by talking about speech acts. Both Austin and Searle operate within the tradition of analytical philosophy, and they illustrate their points by innocent-looking examples like: When stating that it is raining, one is not just providing a description of the weather situation; one is also making a warning that the person that is going to take a walk also remembers to bring an umbrella.

The performative interpretation of language is further elaborated in discourse theory. Here it becomes exposed that through language one can do many more things than make warnings and the like. Through speech acting, one may act out any kind of preconceptions, one can create profound perspectives on an issue, one can promote broad world views, one can be racist or sexist, and one can propagate any kind of political priorities. Discourses form world-views, and ways of acting in the world. Through discourse theory, the performative interpretation of language becomes elaborated into a new profoundness. ${ }^{9}$

\footnotetext{
${ }^{8}$ Carnap (1937) discusses the nature of formal languages without making a restriction to the most elementary formal languages as Wittgenstein apparently did in the $\$ 6$. Through Carnap's work, one gets a detailed elaboration of the picture theory of language, and one reaches the conception that mathematics can be considered the language of science.

${ }^{9}$ See, for instance, Torfing (1999), and Jørgensen and Phillips (2002).
} 
The performative interpretation of language inspires a performative interpretation of mathematics. On different occasions I have argued that mathematics can be interpreted as a discourse. ${ }^{10}$ Consequently, as discourses can form world-views and actions, so can mathematics.

I have previously elaborated on the performative interpretation of mathematics in terms of mathematics in action. I try to exemplify how mathematics constitutes part of different forms of actions, and how mathematics-based actions can have a diverse range of qualities. They can be powerful, benevolent, deceptive, inconsiderate, cynical, altruistic, expensive, risky, violent, etc. There are no particular qualities that one can associate with mathematics-based actions due to the fact that they are mathematics-based. As with any actions, mathematics-based actions call for profound ethical reflections. A performative interpretation of mathematics thus draws ethics into an important dimension of a philosophy of mathematics.

As mentioned above, I am now going to address mathematics in action in terms of the processes of quantifying, digitalising, serialising, categorising, and imagining. I am going to use these five notions as searchlights when looking for the social impact of mathematics. ${ }^{11}$

\section{Quantifying}

The quantification of nature was part of the so-called scientific revolution, and since then it has formed an integral part of the natural sciences. However, procedures of quantification have been utilised far beyond the limits of the natural sciences. One finds quantifications in the social sciences, in psychology, in medicine, in economy, in any form of technical investigation.

The expansion of the scope of quantification, brings about profound ethical issues. Let me here just refer to one example, namely the calculation of the economic value of a human life. The identification of this value has been put on the research agenda for the last hundred years, even though such an identification appears a most questionable example of quantifying. ${ }^{12}$ Several philosophers, including Immanuel Kant, have pointed

\footnotetext{
${ }^{10}$ See, for instance, the Chapter 14 "Mathematics as Discourser" in Skovsmose (2014a), and the article "(Ethno)mathematics as Discourse" (Skovsmose, 2015), See also the Chapter 11 "Beyond the Neutrality of Mathematics" in Ravn and Skovsmose (2019), and Yasukawa, Skovsmose and Ravn (2012, 2016).

${ }^{11}$ I could have used more searchlight as, say, axiomatising and formalising, but such processes are mainly taking place within the domain of mathematics.

${ }^{12}$ See Hood (2017).
} 
out that the value of a human life is unique and so cannot be evaluated, graduated, or subjected to any type of quantification.

Why try to calculate the value of a human being? One answer appears when one considers a health programme implemented by a government. One can think of any such programme as forming part of a humanitarian initiative. A health programme is an effort to save lives and prolong lives. Apparently there is no need for providing any further justification for doing so. However, one can look at a health programme as an investment, and certainly there can be much money put into it. Considering health expenditure as an investment, it becomes consequential to ask about the economic output of the programme. What is the value of the saved lives and of the gained years of life? In order to answer such a question, one needs to identify the economic value of a human life.

One approach for doing this is to consider what a person would be able to produce during the rest of his or her lifetime. Such an approach can be referred to as the classic one, and it has been elaborated in the greatest detail. ${ }^{13} \mathrm{~A}$ more recent approach is to consider life itself a commodity. When considered this way, the value of a life can be interpreted as the amount of money people are willing to pay for it. This value is normally referred to as the value of a statistical life. A procedure for an identification of this value has been outlined in the following way:

\begin{abstract}
Suppose each person in a sample of 100,000 people were asked how much he or she would be willing to pay for a reduction in their individual risk of dying of 1 in 100,000 , or $0.001 \%$, over the next year. Since this reduction in risk would mean that we would expect one fewer death among the sample of 100,000 people over the next year on average, this is sometimes described as "one statistical life saved." Now suppose that the average response to this hypothetical question was $\$ 100$. Then the total dollar amount that the group would be willing to pay to save one statistical life in a year would be $\$ 100$ per person $\times 100,000$ people, or $\$ 10$ million. This is what is meant by the "value of a statistical life". ${ }^{14}$
\end{abstract}

The approach is based on a quantification of peoples' willingness to pay for an expected extension of life.

One can immediately raise objections to such a methodology. A "willingness to pay" might reflect what people might be able to pay. People living in extreme poor conditions are not able to pay much, if anything. According to the outlined procedure for the quantification, the statistical value of their lives could turn out to become close to

\footnotetext{
${ }^{13}$ For an elaboration for a particular human-live value model, see for instance Hofflander (1966). Here one gets an impression for the mathematical complexities such a model might include.

${ }^{14}$ The quotation is taken from the web-page of the United States Environmental Protection Agency: https://www.epa.gov/environmental-economics/mortality-risk-valuation\#means. Accessed 4 May 2020. See also Value of Life: https://en.wikipedia.org/wiki/Value_of_life. Accessed 20 May 2020.
} 
zero. The identification of the value of a statistical life might have a range of consequences, not least with respect to investments in health care programmes. Particular implications might be experienced when it comes to governments' decisions of saving (or not saving) lives or money during an epidemic. Business interests can easily be incorporated in such decisions, when the value of human lives has become quantified.

A recent approach for calculating the value of a human life is to pay attention to the marginal costs of saving a life. ${ }^{15}$ The marginal cost refers to the extra cost of saving one more life. The marginal cost of saving a life can be compared to the marginal revenue of saving a life. By considering marginal costs and marginal revenues, one can locate the discussion within a classical economics framework. It is a common economic insight that when doing any kind of production and one wants to maximise profits, one needs to identify the level of production where the marginal cost equals the marginal revenue. Saving lives turns into a business that might be profitable, at least up to a certain level.

Whatever approach becomes used for defining the economic value of a human life, it opens the way for a variety of cost-benefits analyses, also of the most questionable nature. They can be applied by governments, but also by institutions and companies. As an example, I can refer the Ford Company's way of dealing with the Ford Pinto case. In 1968 , this car model was put in production, but soon it turned out that its fuel system was problematic. When the Pinto model was involved in car accidents, it tended to catch fire. The Ford Company needed to consider whether they should redesign the model such that the fuel tank was placed in a safer position, or whether they should continue the production as it was.

The decision between these two options became based on an explicit economic analysis. Ford calculated the costs of re-designing the model, and the costs of doing nothing. The cost of re-designing the production was estimated to become $\$ 137.000 .000$ US Dollars. The cost of doing nothing drew on the following estimations: 180 burn deaths, 180 serious burn injuries, 2100 burned vehicles. This estimation was naturally based on an extensive amount of already existing statistical information. The further calculation applied the following prises: 200,000 US Dollars per death, 67,000 US Dollars per injured person, and 700 US Dollars per vehicle. An important estimate was the cost of a death, which was what Ford had to pay according to the USA legalisation as being responsible for the accident. The total costs of doing nothing added up to

${ }^{15}$ For an introductory presentation of such an approach, see Thomas (2018). For an elaborated exposition rich of mathematical details, see Thomas and Vaughan (2015). 
49.500.000 US Dollars. The calculations thus gave Ford a clear answer, and Ford continued the production without changing anything. ${ }^{16}$

Here we have reached a profound ethical issue. We arrived there through a route starting with the extended applications of mathematical quantifications. Quantification is not an uncontroversial process. It might appear so when addressing problems in natural sciences, but when quantification becomes stretched out in all directions, it might turn problematic. A quantification can be the carrier of questionable assumptions as, for instance, when it becomes stipulated that it is relevant to quantify the value of a human life. A quantification may direct us deeply into a brutal cynicism with respect both to decisions and to actions.

\section{Digitalising}

In the paper "On Computable Numbers, with an Application to the Entscheidungsproblem", Alan Turing (1937) provides an abstract presentation of the modern computer, although this was not the main purpose of the paper. In the title appears the German word Entscheidungsproblem, which can be translated as "decision problem". The problem was formulated in 1928 by David Hilbert and Wilhelm Ackermann (1958) within a formalism outlook, which at that time was still operating with all its ambitions in place. ${ }^{17}$

The Entscheidungsproblem in its general formulation assumes that we are dealing with a formalised mathematical theory. Considering an arbitrary formula from this formalism, one can ask whether this formula is a theorem or not - in other words, whether or not it can be derived from the axioms of the system. The Entscheidungsproblem raises the question whether there exists an algorithmic procedure for deciding whether an arbitrary formula is a theorem or not.

Turing addressed this question and in doing so, he needed to establish a clear conception of what an algorithmic procedure is. He provided such a conception in terms of an abstract calculating machine that he referred to as an $a$-machine. Later it became renamed as a Turing machine. By specifying the nature of possible calculations, Turing demonstrated that the Entscheidungsproblem "can have no solution" (TURING, 1937, p.

\footnotetext{
${ }^{16}$ For more information about the Ford Pinto case, see Leggett (1999), and Birsch and Fielder (1994).

17 A heavy blow to the formalist ambitions only appeared in 1931 when Gödel (1962) showed that if a formal theory is consistent it cannot be complete. A main ambition of formalism had been to create complete and consistent formal representations of mathematical theories.
} 
231). However, more important might be Turing's conception of the calculating machine, which turned out to be a precise conception of the electronic computer. Any such computer has an equivalent in a Turing machine. This mathematical representation of a computer makes it possible to study the potentials as well as the limits of computing, even before any real computer has been constructed. The Entscheidungsproblem represents an epistemic problem formulated within a formalist outlook. By addressing this problem, Turing conceptualised the electronic computer and opened a broad avenue from pure theoretical issues to real life constructions. ${ }^{18}$

An electronic computer operates with numbers, and digitalisation is a crucial condition for any computing. Within analogue computing, the computational representation of an object has apparent similarities with the original object. In digital computing, the representation is quite different: objects become represented by numbers. The Turing machine shows what can be done with numbers. However, for the electronic computer to be able to operate technically with numbers they need to be in a binary format. This possibility is also due to a mathematical insight, although an old one. In 1689, Gottfried Leibniz (1703) outlined the possibility of calculating within a binary number system. The avenue that leads to the construction of the digital computer is paved with mathematics.

It is common to refer to different industrial revolutions. The First Industrial Revolution is characterised by the invention of a range of new mechanical devices and machines. In 1764, the Spinning Jenny was constructed by James Hargreaves, and in the years following many technical improvements of the spinning technology were introduced. In 1776, the first functioning steam engine was constructed. Before that, James Watt had been experimenting with the power of steam. The construction of the first steam locomotive was completed in 1813. The First Industrial Revolution is characterised by the further development of such technological constructions, and their implementation in the whole domain of production. The Second Industrial Revolution refers to a phase of standardisations and automatisations of production processes. Important elements of this second revolution was the decomposition of work processes into atomic units, known as Taylorism (which we will return to in the following Section 4 "Serialising"), and the invention of the conveyer-belt, which Henry Ford implemented in 1913 in one of his car production factories.

${ }^{18}$ For a further discussion of mechanical procedures and the Turing machine, see Sieg (1994). 
The Third Industrial Revolution has also been referred to as the Digital Revolution. This revolution is characterised by the construction of the electronic computer and its implementation in all spheres of life. This revolution brings about a range of social changes. Automatisations become implemented in all kinds of production processes. The use of robots becomes common, not only in production, but also in, for instance, medicine and war machinery. ${ }^{19}$ Economic transactions become automatised and therefore accelerated. Computer-based patterns of surveillance become implemented in a variety of public and private spaces. The Digital Revolution has brought about dramatic changes of our life-conditions, and mathematics is a part of all of them.

In the first phase of the Digital Revolution, the expected role of the computer was described in optimistic terms. As an example, I can refer to the 1981 book The Microelectronic Revolution, by Tom Forester. However, it is important to recognise the complexities of the social impact accompanying the Digital Revolution. The First Industrial Revolution was accompanied by an extreme oppression and exploitation of the work force. Furthermore, this revolution assumed as a given that the colonial exploitation was maintained at its full scale. As I will be explicit about in the following section "Serialising", devastating patterns of oppression and exploitation might also accompany the Digital Revolution.

The Entscheidungsproblem represented an intrinsic mathematical challenge, and it might be difficult to identify controversial ethical issues related to this problem. However, working with this problem opened a route into further mathematical investigations, technological inventions, and industrial initiatives. This route brought us right into the centre of the Digital Revolution. It brought us as well into an epicentre of ethical controversies. Digitalisation is a mathematics-based act with implications for production processes, working conditions, patterns of control, and intensities of surveillance. Digitalisation has an impact on social and individual life. ${ }^{20}$ Digitalisations provide formations of our life-worlds. ${ }^{21}$

\footnotetext{
${ }^{19}$ For a discussion of the intimate relationship between mathematics and war, see Booss-Bavnbek and Høyrup (2003).

${ }^{20}$ Such impact is, for instance, addresses by Otrel-Cass (2019), and by Bicudo (2020) with a particular reference to the learning and teaching of mathematics.

${ }^{21}$ As described in Skovsmose (2014b), my use of the notion of life-world is different from the use in phenomenology. By life-worlds, I refer to the ways economic, political, and cultural factors format living conditions, and to how we experience such a formatting.
} 


\section{Serialising}

As pointed out by Adam Smith (2009) in The Wealth of Nations, first published in 1776 , the division of labour adds an efficiency to the production process. Instead of being engaged in a complete process, say of making a chair, each worker only completes a particular component of the process. Such a decomposition, I will refer to as a serialisation. $^{22}$ To Karl Marx, serialisations lead directly to alienations of workers subjected to the division of labour. Instead of being engaged in a complete production process, say of a chair, each worker only completes a particular component of the process. ${ }^{23}$

A radical step in the further serialisation of work processes was proposed by Frederick W. Taylor (2006) in The Principles of Scientific Management, first published in 1911. By this publication, the Second Industrial Revolution got under way. In the book, Taylor presents the worker Schmidt, who is going to be exposed to the principles of scientific management. Taylor sees processes of production, or any work processes for that matter, as mechanical processes. The workers and the tools make up part of the same operational structure, which functioning can be optimised through careful schemes of management. The worker thereby becomes part of the process as an object, rather than as an agent of their own life. They become "objectified" and alienated. This is a fundamental part of Marx's analysis of the capitalist mode of production.

The particular work task that Taylor describes concerns how to load pig iron onto a railway wagon. Taylor and his staff had observed that an average worker, following the traditional work pattern, could load $12 \frac{1}{2}$ tons per day. However, Taylor estimated that the quantity could be much more, namely $47-48$ tons per day. To reach such a goal presupposes, however, that a new organisation of the work process becomes implemented. As an illustration of what that could mean, Taylor describes how the worker Schmidt came to work according to the new measures. The important thing is that Schmidt does not follow his own rhythm, but becomes totally subjected to the prescribed organisation of the work process. Schmidt has to be observed by a supervisor, and has to follow what the supervisor orders him to do. Taylor (2006) makes this clear to Schmidt in the following way: "When he tells you to pick up a pig and walk, you pick it up and

\footnotetext{
${ }^{22}$ I was considering to use the term "algoritmization". However, to make an algorithm can be an intrinsic mathematical task, so I prefer "serialisation" that has many more extra-mathematical connotations.

${ }^{23}$ Marx addressed the notion of alienation in his early writings (Marx, 1844), but elaborated it further in the Capital (Marx, 1992, 1993a, 1993b).
} 
walk, and when he tells you to sit down and rest, you sit down. You do that straight through the day" (p. 21)

The overall approach in Taylor's version of scientific management is to turn the worker into a robot. According to scientific management, complex work processes have to be broken down into their atomic units, and which unites to do in what order has to be determined, not by the workers, but by scientific methods. ${ }^{24}$ To me Charles Chaplin's film Modern Times, makes an excellent illustration of what such serialising might imply, both with respect to the format of the work process and the condition of the workers.

Today Taylor's version of scientific management has assumed a new format referred to as New Taylorism or as Digital Taylorism. For implementing Digital Taylorism, the computer plays a principal role. Digital Taylorism shares the basic ambition of classic Taylorism, namely to maximise the efficiency of any work process. However, by means of the computer, the serialising can be taken much further. The smallest atomic tasks can be identified, standardised, and turned into routines. Computerbased serialising also makes it possible to surveil and to control all details of the process, including the people involved in it. The atomic decomposition and the surveilling make it easy to substitute any worker that is not completing the prescribed task in an efficient way by another. Digital Taylorism drains the work processes for any specific personrelated professionalism, as such professionalism becomes incorporated in the computerstructures.

In the article "Big Brother's Corporate Cousin: High-Tech Workplace Surveillance is the Hallmark of an New Digital Taylorism”, Christian Parenti (2001) makes the following observation: "According to the American Management Association, 80 percent of US corporations keep their employees under regular surveillance, and that percentage is growing all the time. From the low-tech body and bag searches at retail stores, to computerized ordering pads at restaurants and the silent monitoring of e-mail and phone traffic in offices, the American workplace is becoming ever more transparent to employers and oppressive for employees." 25 The new Digital Taylorism establishes both an extensive and intensive Big-Brother control system.

Digital Taylorism has also been implemented in school systems. Teaching and learning become broken down into specific units, and the students' learning becomes

\footnotetext{
${ }^{24}$ See also the presentation of Taylorism in the Chapter 15 "Symbolic Power, Robotting, and Surveilling" in Skovsmose (2014a).

${ }^{25}$ See also Lanigan (2007).
} 
defined in terms of the mastering of well-defined tasks. It is a part of Digital Taylorism that the students' learning becomes checked along the route, making it possible to include loops and repetitions in the process. The role of the teacher also gets specified and becomes easy to observe and to control. Learning and teaching turns into serialised tasks, and students and teachers come to operate in a digital panopticon.

With particular reference to the situation in the USA, Terry M. Moe (2003) makes the following observation with respect to the implementation of Digital Taylorism in school systems: "The movement for school accountability is essentially a movement for more effective top-down control of the schools. The idea is that, if public authorities want to promote student achievement, they need to adopt organizational control mechanismstests, school report cards, rewards and sanctions, and the like-designed to get district officials, principals, teachers, and students to change their behaviour in productive ways. [...] Virtually all organizations need to engage in top-down control, because the people at the top have goals they want the people at the bottom to pursue, and something has to be done to bring about the desired behaviours. [...] The public school system is just like other organizations in this respect ...” (p. 81). ${ }^{26}$ Digital Taylorism captures the school system in the format of a production process that, like any such process, need to be optimised and controlled.

The implementation of New Taylorism in workplaces and schools systems is propelled forward by mathematical means. New Taylorism represents a digitalised serialising with an impact on all features of our life-worlds. As a consequence, this whole development calls for an attention to ethical considerations. However, let me make an observation with respect to my use of the word ethics. I have considered talking about the politics of mathematics instead of about mathematics and ethics. I am interested in addressing the full range of the social impact of mathematics, whatever we are dealing with work processes, educational processes, or any other area where mathematics is brought in action. This calls for considering the politics of mathematics as representing a fourth dimension of a philosophy of mathematics. However, I will continue to talk about mathematics and ethics, always having in mind also the controversial issues that can be associated with a politics of mathematics.

\footnotetext{
${ }^{26}$ For a critical investigation of the New Taylorism in the USA school system, see Au (2011). The quotation
} of Moe is also taken from there. 


\section{Categorising}

In Critique of Pure Reason, first published in 1781, Immanuel Kant (1929) created a radical new way of looking at mathematics. Since the Scientific Revolution, it had been acknowledged that mathematics plays a fundamental role in the description of nature. The generally accepted explanation was that this was due to properties of nature. The laws according to which nature was operating had a mathematical format; as a consequence, mathematics provides the best possible tool for describing nature. Kant agreed that mathematics was powerful in capturing our observations of nature. However, according to him the reason was not due to any properties of nature, but to properties of the epistemic structures we, as human beings, bring into action when we observe natural phenomena. Since all our observations of natural phenomena take place in space and time, and that mathematics captures the properties of space and time, mathematics will apply to any such observation. Mathematics is an integral component of our epistemic categories that become projected onto whatever we observe. According to Kant, this is the reason for the general applicability of mathematics.

At times Michel Foucault has been referred to as the new Kant, and this is with good reason. Foucault was also deeply concerned with the formation or our knowledge, or rather with what we assume to be our knowledge. He also found that what we consider knowledge is formed through categories. However, quite different from Kant, Foucault considered these categories to be social fabrications. Such fabrications take place though complex historical processes that might incorporate all kinds of assumptions and preconceptions. Prejudices from different historical periods might be engraved in our categorical frameworks. Based on such categorises, we express what we think of as our knowledge. ${ }^{27}$

In our digitalised world, mathematics becomes part of the formatting of our knowledge. How could that be? When we search the net, information appears on the screen in front of us. Apparently, we are in charge of what we are doing. We type a search word and see what appears. We might click our way onto some other web-pages. We can change the search word, if we want. We appear to be free in our walk on the net. We seem

${ }^{27}$ See, for instance, Foucault $(1994,2000)$. 
perfectly in charge of what we are doing. We might claim that we construct our knowledge based on what we locate on the net. ${ }^{28}$

However, what appears on the screen is not simply determined by our choices and priorities. What appears is a pre-fabricated phenomenon. Our walk on the net is not any kind of free walk; it is a guided and pre-structured walk. Google's search engine is set into operation whenever we are searching. This engine is based on a mathematically elaborated PageRank model, which provides a ranking of web pages. As there are millions and millions of such pages, a random search would be without meaning. It would be like searching information in a library, where all the leaves have been torn out from the books and put in a pile at the middle of the floor. The web-pages need to be organised, and this is done by the PageRank model. This model, however, establishes all kind of priorities with respect to our search for information. One can think of it as a knowledge-structuring mathematical device.

The PageRank model applies linear algebra and in particular matrix calculations. One parameter in these calculations is the number of links a web-page has got; this parameter is interpreted as an expression of the importance of the page. A collection of such priorities structures the page ranking. Huge business interests are associated to this ranking; it might be crucial to appear as one of the first pages in a search. Besides economic interests, any kind of stereotypes might also be incorporated in the ranking. As an example, previously a search for "lesbian" would bring the search on to pornographic pages. This stereotypical association has now been removed from the PageRank model, but many other stereotypes can be operating through the model, and still new stereotypes might become incorporated. ${ }^{29}$

That PageRank model provides a mathematical structuring of our walk on the net and therefore of the information we get from that. It is not any idealised structuring as suggested by Kant. Is it an industrial structuring, which might include many kinds of assumptions, presumptions, and preconceptions. It might include economic as well as political interest. It is a structuring with a tremendous impact on social life. It has an impact on what we might come to know about and what we come to ignore. It is not only Google that provides rankings of information. What we see and not see on Facebook has

${ }^{28}$ For a further discussion of the PageRank model, see Langville and Meyer (2012), and Ravn and Skovsmose (2019).

${ }^{29}$ See Barros (in preparation). 
also been subjected to algorithmic-based rankings. Any such structuring of information is in need of profound ethical reflections.

\section{Imagination}

The notion of sociological imagination was coined by Charles Wright-Mills (1959). It was formulated as part of a critique of logical positivism, according to which all sciences, also social sciences, should provide descriptions of the actual state of affairs. ${ }^{30}$ By the notion of sociological imagination, Wright-Mills stepped away from this position and claimed that social theorising also has to conceptualise alternatives to present states of affairs.

On several occasions, I have talked about technological imagination. By this notion I refer to the conception of technological possibilities that do not exist, but might come to exist. ${ }^{31}$ The First Industrial Revolution were initiated through several examples of technological imagination as the conception of the spinning machine and of the steam engine. Such imaginations anticipated mechanical constructions. For articulating such imaginations no advanced mathematics were put in operation. ${ }^{32}$ In arriving at the Digital Revolution, technological imagination has also been put in operation. However, contrary to what characterised the First Industrial Revolution (and also the Second Industrial Revolution), mathematics plays the principal role in forming the technological imagination that bring us into the Third Industrial Revolution. The conception of the digital computer was impossible without mathematics.

Technological imagination opens up the way for new possibilities. The connotations of the word "possibility" normally indicate that we are dealing with attractive potentials. However, we need to broaden up this interpretation. I use the word "possibility" to include positive and attractive phenomena as well as risks, dangers, if not catastrophes. By possibility I refer to what might come to take place in the future; this means that possibility is intimately connected to uncertainty. Future technical possibilities will become formed through technological imaginations, and today in particular by mathematics-based technological imaginations. ${ }^{33}$

\footnotetext{
${ }^{30}$ For a presentation of logical positivism, see, for instance Ayer (1959).

${ }^{31}$ See, for instance, Skovsmose (2014a).

${ }^{32}$ However, when the outputs of a mechanical imaginations has to be constructed, mathematics becomes crucial. For the construction of, say, a locomotive, one needs to provide a geometric presentation in order to analyse its details.

${ }^{33}$ Technological determinism refers to the assumption that the technological development is the principle force in social development. I do not assume any such determinism. Technological development operates on the global scene together with political struggles, economic forces, and social movements. It is a dramatic and open-ended process.
} 
That possibilities can have all kind of qualities is clearly illustrated by the First Industrial Revolution. A new efficiency in production was created simultaneously with new degrees of exploration of workers as well as of nature. The possibilities that can be associated to the Third Industrial Revolution can also have a range of qualities. As we are still living through this revolution, we are surrounded by all its uncertainties.

We bring the pollution of today together with us into the future. Will we be able to cope with this? What environmental policies might become implemented? Which dangers might be overlooked, or maybe deliberately ignored? Will new soluble forms of plastic be invented? Will we be able to clean up the oceans? What climate changes can we expect? Will we find alternative energy resources? How will search for energyalternatives becomes prioritised? Will huger crises turn global? Will new patterns of food production become developed? Will new patterns for redistributing wealth and resources become implemented? Will production processes get further accelerated? Will we come to experience unprecedented patterns of serialising and surveillance. Big Brothering might get intensive, and face-recognition might become a most common technique applied in public spaces. New patterns of social dumping might be brought in operation. The distribution of information as well as of misinformation might find new channels with the implication that it gets even more difficult to distinguish between information and misinformation. ${ }^{34}$

We do not know the responses to any of these potential uncertainties. Except for one thing: Mathematics-based technological imagination will be brought in operation when dealing with issues about pollution, inventions of new material, search for alternative energy resources, further development of farming, redistribution of wealth and resources, acceleration of production, serialising, surveilling, face recognition, and means of information.

Our life-worlds are formed through what is actually the case as well as from what might become the case. What we experience as our life-world, it not just composed of the actual space of facts. It is also composed of possibilities including risks and dangers. It is composed of "what is" and of "what might-become". In our present situation, very many "might-becomes" will be established through mathematics-based technological imaginations.

Imagination appears a simple personal act. One can imagine so many different things. However, via the idea of the sociological imagination, the notion gets a political interpretation. It is a political act to imagine alternatives to an actual social situation. It

\footnotetext{
${ }^{34}$ In Skovsmose (2019), I have discussed how mathematics might contribute to the formation of critical situations.
} 
can be a most radical political act. Via the notion of technological imagination, one more feature becomes added. The technological imagination is an important creative force in bringing about new technological possibilities, also possibilities that might have devastating implications. Technological imagination is a controversial and open-ended act. Since much technological imagination is mathematics-based, socio-political issues become crucial for a philosophy of mathematics. They constitute its ethical dimension.

\section{Banality of Mathematical Expertise}

As mentioned in the introduction, by concentrating on ontological and epistemological issues the classic positions in the philosophy of mathematics come to operate within an ethical vacuum. Let us now take a closer look at a more recent trend in the philosophy of mathematics, referred to as the "philosophy of mathematical practice".

One of the first to articulate this trend was Ruben Hersh (1979). He found that the philosophy of mathematics had developed with a pathological degree of inbreeding, due to the focus on the classics: logicism, formalism, and intuitionism. The discussed problems had been formulated with reference to already formulated philosophical problems, not acknowledging the problems emerging from the actual mathematical practice. Hersh suggested making a turn in the philosophy of mathematics by paying attention to the mathematical practice. By such a practice he first of all referred to what was taking place at universities and other research institutions, and not to practice as referred to by, say, ethnomathematical approaches.

The trend "philosophy of mathematical practice" follows Hersh's recommendation. As an illustration of what this could mean, we can take a look at the book The Philosophy of Mathematical Practice, edited by Paolo Mancosu (2008). In the preface he highlights that he wants to "unify the efforts of many philosophers who were making contributions to a philosophy of mathematics informed by a desire to account for many central aspects of mathematical practice that, by and large, had been ignored by previous philosophers and logicians" (p. v).

The book addresses a range of issues related to ways of doing mathematics, and let me refer to three examples. Marcus Giaquinto (2008) explores the role of visualisation in mathematics both with respect proving and discovering. According to a traditional formalist approach, visualisation might be relevant for making mathematical discoveries, but it has no role to play in mathematical proving. This dichotomy is challenged by Giaquinto. Kenneth Manders (2008) investigates diagram-based geometric practices in 
order to provide a route towards "rigorous diagram-based reasoning practice" (p. 75). This is also a route that runs contrary to formalism. ${ }^{35}$ Jeremy Avigad (2008) discusses the use of computers in mathematical inquiries. By doing so he mixes empirical features with mathematical processes, while in classic approaches in the philosophy of mathematics this is considered problematic. Avidag makes the following observation which appears programmatic for a philosophy of mathematical practice: "The types of questions raised here are only meaningful in specific mathematical and scientific contexts, and a philosophical analysis is only useful in so far as it can further such inquiry. Ask not what the use of computers in mathematics can do for philosophy; ask what philosophy can do for the use of computers in mathematics" (p. 314) (16 $^{36}$

Most often university studies in mathematics becomes defined through wellspecified curricula including topics like linear algebra, calculus I, calculus II, probability theory, non-Euclidian geometry, universal algebra, topology, differential geometry, etc. There is no mention of disciplines that might address ethical issues related to the production and application of mathematical knowledge. The social impact of bringing mathematics into action is ignored. Apparently, in the vast majority of study programmes in mathematics, ethical issues are considered irrelevant. However, this does not mean that such study programmes maintain any ethical neutrality. Mathematics is performative, it becomes brought in action. Mathematics contributes to processes of quantifying, digitalising, serialising, categorising, and imagining. Such social impacts might have any kind of qualities and serve any kind of interests. To assume that operating with mathematics can be neutral is an ideological illusion - an illusion propagated by a twodimensional philosophy of mathematics.

Inserting mathematics into an ethical vacuum is repeated by the philosophy of mathematical practice. In the book The Philosophy of Mathematical Practice, there is no discussion of any ethical issues. In the book, the very word "ethics" only appears once (and this is in a parenthesis).

The ignorance of the ethical dimension of a philosophy of mathematics, both in the actual practice of mathematics and in the philosophy of mathematical practice, I consider a huge problem. I consider it to be the most profound problem confronting a philosophy of mathematics today. The nature of this problem I have referred to as a

\footnotetext{
${ }^{35}$ For a discussion of formal and informal provability, see Leitgeb (2009).

${ }^{36}$ More presentations of the philosophy of mathematical practice can be found in Carter (2019), Ferreirós (2016), and Tymoczko (1986).
} 
banality of mathematical expertise (SKOVSMOSE, 2020). Let me just indicate why I use this metaphor.

In 1963 Hanna Arendt (1977) published the book Eichmann in Jerusalem: A Report on the Banality of Evil, where she reports on the trail of Adolf Eichmann that took place in 1962. To Arendt, Eichmann did not appear as being any dedicated Nazis attacking the Jewish people. He appeared rather an anonymous administrator who claimed that he had tried to do his best in a most difficult situation. To organise the transportation of Jewish people to the extermination camps was a huge challenge due to the lack of means of transportation as well as the difficulties of locating reliable routes of transport. However, Eichmann succeeded in doing so in an efficient way. He highlighted also that he had followed orders and done what he was supposed to do. Eichmann never appeared to have been reflecting on the implications of what he had been doing. This is what Arendt refers to as a banality of evil. Eichmann appeared to have been operating in an ethical vacuum.

Arendt's presentation of the Eichmann case inspired me to use the notion of banality of mathematical expertise. By this expression I want to highlight an extreme problematic feature of the mathematical practice: that it seems to operate in an ethical vacuum. At the universities the formation of the mathematical expertise concentrates on making the students able to do mathematics. There is no emphasis on engaging students in reflecting on the possible social impacts of doing mathematics.

Mathematics-based actions might have all kind of implications. I have tried to illustrate this by using the searchlights of quantifying, digitalising, serialising, categorising, and imagining along the routes connecting mathematics with contentious social issues. I believe it is crucial that the impacts of bringing mathematics into action become critically addressed as part of both a mathematical practice and a philosophy of mathematics. The ethical dimension of a philosophy of mathematics is an indispensable component of this philosophy.

\section{Acknowledgements}

I want to thank Denner Dias Barros, Manuella Carrijo, Ana Carolina Faustino, Peter Gates, Miriam Godoy Penteado, and Daniela Alves Soares for their helpful comments and suggestions. 


\section{References}

ARENDT, H. Eichmann in Jerusalem: A report on the banality of evil. New York: Penguin Books, 1977.

AU, W. Teaching under the new Taylorism: High-stakes testing and the standardization of the 21st century curriculum. Journal of Curriculum Studies, v. 43, n. 1, p. 25-45, 2011.

AUSTIN, J. L. How to do things with words. Oxford: Oxford University Press, 1962.

AVIGAD, J. Computers in mathematical inquiry. In: MANCOSU, P. (ed.). The philosophy of mathematical practice. Oxford: Oxford University Press, 2008. p. 302-316.

AYER, A. J. (ed.). Logical positivism. New York: The Free Press. 1959.

BARROS, D. D. Lendo e escrevendo o mundo com a matemática em um movimento social: Discussões sobre representatividade e as lutas da comunidade LGBT+. Doctoral dissertation. Rio Claro, SP: Universidade Estadual Paulista (UNESP), (in preparation).

BERNACERRAF, P.; PUTNAM, H. (eds.). Philosophy of mathematics. Englewood Cliffs, NJ: Prentice-Hall, 1964.

BICUDO, M. A. V. (ed.). Constitution and production of mathematics in the cyberspace: A phenomenological approach. Cham: Springer, 2020.

BIRSCH, D.; FIELDER, J. H. (eds.). The Ford Pinto case: A study in applied ethics, business, and technology. New York: State University of New York, 1994.

BOSTOCK, D. Philosophy of mathematics: An introduction. Chichester: Wiley Blackwell, 2009.

BROWN, J. R. Philosophy of mathematics: A contemporary introduction to the world of proofs and pictures. Second Edition. New York and London: Routledge, 2008.

BUENO, O.; LINNEBO Ø. (eds.). New waves in philosophy of mathematics. Houndmills: Palgrave Macmillan, 2009.

BOOSS-BAVNBEK, B.; HØYRUP, J. (eds.). Mathematics and war. Basel, Boston, Berlin: Birkhäuser, 2003.

BROUWER, L. E. J. Intuitionism and formalism. Bulletin of the America Mathematical Society, v. 20, n. 2, p. 81-96, 1913. Reprinted In: JACQUETTE, D. (ed.). Philosophy of mathematics: An anthology. Oxford: Blackwell, 2002. p. 269-276.

CARNAP, R. The logical syntax of language. London: Routledge and Kegan Paul, 1937.

CARTER, J. Philosophy of mathematical practice: Motivations, themes and prospects.

Philosophia Mathematica, v. 27, n. 1, 1-32, 2019.

ERNEST, P. Social constructivism as a philosophy of mathematics. New York: State University of New York Press, 1998.

ERNEST, P. A dialogue on the ethics of mathematics. The Mathematical Intelligencer, v. 38, n. 3, 69-77, 2016. 
ERNEST, P. The ethics of mathematics: Is mathematics harmful? In: ERNEST, P. (ed.). The philosophy of mathematics education today. Cham: Springer, 2018. p. 187-216.

FERREIRÓS, J. Mathematical knowledge and the interplay of practices. Princeton, NJ: Princeton University Press, 2016.

FORESTER, T. The microelectronic revolution, Cambridge, MA: The MIT Press, 1981.

FOUCAULT, M. The order of things: An archaeology of the human sciences. New York: Vintage Books, 1994.

FOUCAULT, M. Power. New York: The New Press, 2000.

FREGE, G. Begriffsschrift: A formula language, modelled upon that of arithmetic, for pure thought. In: VAN HIEJENOORT, J. (ed.). From Frege to Gödel: A source book in mathematical logic, 1879-1931. Cambridge, MA: Harvard University Press, 1967. p. 1-82.

FREGE, G. Die Grundlagen der Arithmetik/The foundations of arithmetic. Oxford: Blackwell, 1978.

GEORGE, A.; VELLEMAN, D. J. Philosophies of mathematics. Oxford: Blackwell, 2002.

GIAQUINTO, M. Visualizing in mathematics. In: MANCOSU, P. (ed.). The philosophy of mathematical practice. Oxford: Oxford University Press, 2008. p. 22-42.

GÖDEL, K. On formally undecidable propositions of Principia Mathematica and related systems. New York: Basic Book, 1962.

HACKING, I. Why is there philosophy of mathematics at all? Cambridge: Cambridge University Press, 2014.

HERSH, R. Some proposals for reviving the philosophy of mathematics. Advances in Mathematics, v. 31, p. 31-50, 1979.

HERSH, R. Mathematics and ethics. Humanistic Mathematics Network Journal, v. 5, n. 9, p. 20-23, 1990.

HILBERT, D. Neubegründung der Mathematik: Erste Mitteilung. Abhandlungen aus dem Seminar der Hamburgischen Universität, , v. 1, p. 157-177, 1922.

HILBERT, D. ; ACKERMANN, W. Principles of mathematical logic. Providence, RI: Chelsea Publishing Company, 1958.

HOFFLANDER, A. E. The human life value: A theoretical model. The Journal of Risk and Insurance, v. 33, n. 4, p. 529-536, 1966.

HOOD, K. The science of value: Economic expertise and the valuation of human life in US federal regulatory agencies. Social Studies of Science, v. 47, n. 4, p. 441-456, 2017.

JACQUETTE, D. (ed.). Philosophy of mathematics: An anthology. Oxford: Blackwell, 2002.

JØRGENSEN, M. W.; PHILLIPS, L. Discourse analysis as theory and method. London: Sage, 2002. 
KANT, I. Critique of Pure Reason. Translated by Norman Kemp Smith. London: MacMillan, 1929.

KÖRNER, S. The philosophy of mathematics. London: Hutchinson University Library, 1968.

LANGVILLE, A. N.; MEYER, C. D. Google's PageRank and beyond: The science of search engine rankings. Princeton, NJ: Princeton University Press, 2012.

LANIGAN, C. From assembly line to just-in-time: Preparing a capable workforce for the knowledge economy. CIO, 2007. https://www.cio.com/article/2439128/from-assembly-line-tojust-in-time--preparing-a-capable-workforce-for-the-knowledge-economy.html. Accessed: 18 May 2020.

LEGGETT, C. The Ford Pinto case: The valuation of life as it applies to the negligence efficiency argument, 1999. https://users.wfu.edu/palmitar/Law\&Valuation/Papers/1999/Leggettpinto.html. Accessed 8 May 2020.

LEIBNIZ, G. Explanation of binary arithmetic, 1703. http://www.leibniztranslations.com/binary.htm. Accessed 30 May 2020.

LEITGEIB, H. On formal and informal provability. In: BUENO, O.; LINNEBO, Ø. (eds.), New waves in philosophy of mathematics. Houndmills: Palgrave Macmillan, 2009. p.263-299.

LINNEBO, Ø. Philosophy of mathematics. Princeton, NJ. Princeton University Press, 2017.

MANDERS, K. Diagram-based geometric practice. In: MANCOSU, P. (ed.). The philosophy of mathematical practice. Oxford: Oxford University Press, 2008. p. 65-79.

MANCOSU, P. (ed.). The philosophy of mathematical practice. Oxford: Oxford University Press. 2008.

MARX, K. Economic and Philosophic manuscripts of 1844, 1844.

https://www.marxists.org/archive/marx/works/download/pdf/Economic-PhilosophicManuscripts-1844.pdf. Accessed: 5 June 2020.

MARX, K. Capital: A critique of political economy, I-III, London: Penguin Classics, 1992, 1993a, 1993b.

MEHLBERG, H. The present situation in the philosophy of mathematics. Synthese, v. 12, n. 4, 380-414, 1960. Reprinted In: JACQUETTE, D. (ed.). Philosophy of mathematics: An anthology. Oxford: Blackwell, 2002. p. 65-82.

MOE, T. M. Politics, control, and the future of school accountability. In: PETERSON, P. E.; WEST, M. R. (eds.). No child left behind? The politics and practice of school accountability. Washington, DC: Brookings Institution Press, 2003. p. 80-106.

OTREL-CASS. K. (ed.). Hyperconnectivity and digital reality: Towards the eutopia of being human. Cham: Springer, 2019.

PARENTI, C. Big brother's corporate cousin: High-tech workplace surveillance is the hallmark of a new digital Taylorism. The Nation, v. 273, n. 5, p. 26-30, 2001.

https://www.thenation.com/article/archive/big-brothers-corporate-cousin/. Accessed: 25 May 2020 
RAVN, O.; SKOVSMOSE, O. Connecting humans to equations: A reinterpretation of the philosophy of mathematics. Cham: Springer, 2019.

RESTIVO, S. Mathematics in society and history. Dordrecht: Kluwer, 1992.

RESTIVO, S., BENDEGEM, J. P. V.; FISHER, R. (eds.). Math worlds: Philosophical and social studies of mathematics and mathematics education. New York: State University of New York Press, 1993.

SEARLE, J. Speech acts. Cambridge: Cambridge University Press, 1969.

SHAPIRO, S. Thinking about mathematics: The philosophy of mathematics. Oxford: Oxford University Press, 2000.

SIEG, W. Mechanical procedures and mathematical experience. In: GEORGE, A. (ed.) Mathematics and mind, Oxford: Oxford University Press,1994. p. 71-117. Reprinted In: JACQUETTE, D. (ed.). Philosophy of mathematics: An anthology. Oxford: Blackwell, 2002. p. 226-258.

SKOVSMOSE, O. Critique as uncertainty. Charlotte, NC: Information Age Publishing, 2014a.

SKOVSMOSE, O. Foregrounds: Opaque stories about learning. Rotterdam: Sense Publishers, 2014b.

SKOVSMOSE, O. (Ethno)mathematics as discourse. Bolema (Boletim em Educação Matemática - Mathematics Education Boletim), v. 29, n. 51, p. 18-37, 2015. Reprinted In: BERGSTEN, C.; SRIRAMAN, B. (eds.), Refractions of Mathematics Education: Festschrift for Eva Jablonka. Charlotte, NC: Information Age Publishing, 2015. p. 155-172.

SKOVSMOSE, O. Crisis, critique and mathematics. Philosophy of Mathematics Education Journal, n. 35, 2019.

SKOVSMOSE, O. Banality of mathematical expertise. ZDM Mathematics Education, v. 52, n. 6, 2020.

SMITH, A. The wealth of nations. Blacksburg, VA: Thrifty Books, 2009.

TAYLOR, F. W. The principles of scientific management. New York: Cosimo Classics, 2006.

THOMAS, P. Calculating the value of human life: Safety decisions that can be trusted. Policy Report 25. University of Bristol, 2018. https://www.bristol.ac.uk/medialibrary/sites/policybristol/PolicyBristol-Report-April-2018-value-human-life.pdf. Accessed 8 May 2020.

THOMAS, J. P.; VAUGHAN, G. J. Testing the validity if the "value of a prevented fatality" (VPF) used to assess UK safety measures. Process Safety and Environmental Protection, v. 93, p. 293-298, 2015.

https://www.sciencedirect.com/science/article/pii/S0957582014000962?via\%3Dihub. Accessed 8 May 2020.

TORFING, J. New theories of discourse: Laclau, Mouffe and Žižek. Oxford: Wiley-Blackwell, 1999. 
TURING, A. M. On computable numbers, with an application to the Entscheidungsproblem. Proceeding of the London Mathematical Society, s2-v. 42, n. 1, p. 230-265, 1937.

TYMOCZKO, T. (ed.). New directions in the philosophy of mathematics. Boston: Birkhäuser, 1986.

WHITEHEAD, A.; RUSSELL, B. Principia mathematica I-III. Cambridge: Cambridge University Press, 1910-1913.

WITTGENSTEIN, L. Remarks on the foundations of mathematics. Oxford: Basil Blackwell, 1978.

WITTGENSTEIN, L. Wittgenstein's lectures on the foundations of mathematics:

Cambridge, 1939. Edited by Cora Diamond. Chicago: University of Chicago Press, 1989.

WITTGENSTEIN, L. Tractatus logico-philosophicus. With an Introduction by Bertrand Russell. London and New York: Routledge, 1992.

WITTGENSTEIN, L. Philosophical investigations. Oxford: Blackwell Publishers, 1997.

WRIGHT MILLS, C. The sociological imagination. Oxford: Oxford University Press, 1959.

YASUKAWA, K.; SKOVSMOSE, O.; RAVN, O. Mathematics as a technology of rationality: Exploring the significance of mathematics for social theorising. In: SKOVSMOSE, O.; GREER, B. (eds.). Opening the cage: Critique and politics of mathematics education. Rotterdam: Sense Publishers, 2012. p. 265-284.

YASUKAWA, K., SKOVSMOSE, O. \& RAVN, O. Scripting the world in mathematics and its ethical implications. In: ERNEST, P.; SRIRAMAN, B.; ERNEST, N. (eds.). Critical mathematics education: Theory, praxis, and reality. Charlotte, NC: Information Age Publishing, 2016. p. 81-98.

Received in: August 02, 2020.

Accepted on: September 10, 2020. 